\title{
Physicochemical, microbiological and sensory assessments of Italian salami sausages with probiotic potential
}

\author{
Juliana Nogueira Ruiz ${ }^{1}$, Nilda D. Montes Villanueva ${ }^{2}$, Carmen Silvia Favaro-Trindade ${ }^{3}$, Carmen J. Contreras-Castillo ${ }^{\text {* }^{*}}$
}

\author{
IUniversity of São Paulo/ESALQ - Dept. of Agroindustry, \\ Food and Nutrition, Av. Pádua Dias, 11 - 13418-900 - \\ Piracicaba, São Paulo - Brazil. \\ 2Pontifical Catholic University of Peru/CENTRUM, Jr. Daniel \\ Alomía Robles, 125, Los Álamos de Monterrico - Surco, \\ Lima - Peru. \\ ${ }^{3}$ University of São Paulo/FZEA - Dept. of Food Engineering, \\ Av. Duque de Caxias Norte, 225 - 13635-900 - \\ Pirassununga, São Paulo - Brazil. \\ *Corresponding author <ccastill@usp.br>
}

Edited by: Paulo Cesar Sentelhas

Received June 18, 2013

Accepted December 17, 2013

\begin{abstract}
Probiotics are live microorganisms that confer a health benefit on the host by improving the intestinal microbial balance. We evaluated the viability of Lactobacillus acidophilus (La) and Bifidobacterium lactis (BI) probiotics and their effects on the technology and sensorial characteristics of fermented sausage. The presence of probiotic cultures reduced water activity and promoted faster $\mathrm{pH}$ reduction in the salamis, which presented $\mathrm{pH}$ values between 4.71 and 5.23 and water activity between 0.84 and 0.89 . Lactic acid content ranged between 0.19 and 0.29 $\mathrm{g}$, and the samples lost up to $35 \%$ of their weight during ripening. As regards color, no differences were found between the probiotic salamis and the control, presenting an overall mean of 40.85 for $L^{*}$ (lightness), 14.48 for $a^{*}$ (redness) and 6.46 for $b^{*}$ (yellowness). High consumer acceptance was observed for the probiotic salamis, which showed an average acceptance of approximately 7.0 on a nine-point hedonic scale for all attributes evaluated, with no differences $(p \leq 0.05)$ when compared with the control. The performance of La was better, as the salamis treated with this microorganism presented less weight loss, better acceptance and greater purchase intention. Flavor and texture were the attributes that most influenced sensory acceptance. Salamis supplemented with probiotic cultures may be a viable option for the formulation of fermented sausages in the food industry. Keywords: Lactobacillus acidophilus, Bifidobacterium lactis, fermented meat sausage, functional food, sensory acceptance
\end{abstract}

\section{Introduction}

Health and wellness is one of the major consumer trends in the food industry. Consequently, manufacturers are constantly looking for new ways to incorporate natural and innovative ingredients such as probiotics and prebiotics into food products for health benefits. Probiotics have been defined as "live microorganisms which, when administered in adequate amounts, confer a health benefit on the host" by improving the intestinal microbial balance (FAO, 2001). Most probiotics contain Lactobacillus acidophilus and Bifidobacterium, which are frequently used in food products and are both normally present in the human gastrointestinal tract (Dali and Davis, 1998). The use of both types of probiotic has further increased due to their reduced acidification during post-processing storage and their relatively high yield of $\mathrm{L}(+$ )-lactic acid. The application of Bifidobacterium spp. and Lactobacillus acidophilus probiotic microorganisms in dry fermented meat products is not yet common.

The main characteristics of these probiotic strains are acid and bile salt resistance (Prasad et al., 1998). Most lactobacilli already have a beneficial effect in the small intestine, whereas the largest numbers of bifidobacteria are often found in the colon. Both probiotics are also reported to synthesize folic acid, niacin, thiamine, riboflavin, pyridoxine and vitamin $\mathrm{K}$, which are slowly absorbed by the body (Tamine et al., 1995). L. acidophilus exhibits antagonistic activity against pathogenic bacteria, which are foodborne disease agents (Sanders and Klaenhammer, 2001). Bifidobacteria survive intestinal transit because after consumption, the strain can be recovered from the feces (Gopal et al., 2001). This survival may be due to resistance to acid, bile and pancreatic enzymes.

Dry fermented sausages, such as salami-type raw cured sausages, are the result of several factors that act in synergy to yield specific characteristics during ripening. These biochemical reactions result in the formation of metabolic end-products (Paramithios et al., 2010). This type of product does not need thermal treatment during manufacturing or prior to consumption, as it is stable and safe (Vignolo et al., 2010). This process favors the growth of desirable microorganisms, especially lactic acid bacteria (LAB), that influence sensorial and nutritional qualities and safety (Martín et al., 2007).

This study aimed to evaluate the effects of the addition of two probiotic cultures on the physicochemical and microbiological characteristics and sensory acceptance of Italian salamis.

\section{Materials and Methods}

\section{Sausage manufacture}

Italian salami with the following composition was prepared: pork shoulder $\left(600 \mathrm{~g} \mathrm{~kg}^{-1}\right)$, beef rib $\left(200 \mathrm{~g} \mathrm{~kg}^{-1}\right)$ and pork back fat $\left(200 \mathrm{~g} \mathrm{~kg}^{-1}\right)$ from the lumbar region, obtained from a local supermarket. Additionally, the following common ingredients were added to the meat mixture in each treatment: sodium nitrite $\left(150 \mathrm{mg} \mathrm{kg}^{-1}\right)$ and nitrate $\left(150 \mathrm{mg} \mathrm{kg}^{-1}\right)$, sodium chloride $\left(25 \mathrm{~g} \mathrm{~kg}^{-1}\right)$, sucrose $\left(4 \mathrm{~g} \mathrm{~kg}^{-1}\right)$, dextrose $\left(7.5 \mathrm{~g} \mathrm{~kg}^{-1}\right)$, maltodextrin $\left(5 \mathrm{~g} \mathrm{~kg}^{-1}\right)$, sodium erythorbate $\left(5 \mathrm{~g} \mathrm{~kg}^{-1}\right)$, monosodium glutamate $\left(1 \mathrm{~g} \mathrm{~kg}^{-1}\right)$, white pepper $\left(2 \mathrm{~g} \mathrm{~kg}^{-1}\right)$, nutmeg (1 $\left.\mathrm{g} \mathrm{kg}^{-1}\right)$, coriander $\left(1 \mathrm{~g} \mathrm{~kg}^{-1}\right)$ and garlic powder $\left(2 \mathrm{~g} \mathrm{~kg}^{-1}\right)$. 
A commercial starter culture containing Staphylococcus xylosus DD-34 and Pediococcus pentosaceus PC-01 was supplied at the concentration recommended by the manufacturer $\left(125 \mathrm{mg} \mathrm{kg}^{-1}\right)$. The probiotics $\left(10 \mathrm{~g} \mathrm{~kg}^{-1}\right) L$. acidophilus and B. lactis were also used.

Chilled beef and pork meat was pre-weighed and cut. The chilled meat and frozen pork back fat were ground separately using a grinder with stainless steel disks with 10, 5, and $8 \mathrm{~mm}$ holes for the pork, beef and pork back fat, respectively. We initially added the pork and beef meat, followed by the pork back fat. After mixing the raw meat, non-meat ingredients were added: a pre-hydrated starter culture (the proportion of water was $0.75 \%$ of the meat batter), lyophilized probiotics, sugar, maltodextrin and antioxidants. The meat batter was manually stuffed into reconstituted collagen casings measuring $45 \mathrm{~mm}$ in diameter.

The sausages were hand linked to standard sizes (250 g each) and then hung from metal rods and placed in a fermentation chamber, where they remained at 23 to $25^{\circ} \mathrm{C}$ for $24 \mathrm{~h}$, with a humidity (RH) of 85 to $90 \%$, to reach a $\mathrm{pH}$ between 5.0 and 5.4. Later, the sausages were taken to a ripening chamber, which operated at a temperature of between 17 and $19{ }^{\circ} \mathrm{C}$ and at 70 to 75 $\% \mathrm{RH}$. The sausages remained there for 12 to 13 days, until the water activity was between 0.87 and 0.88 . The final product was packaged under vacuum packaging (a multilayered ethylene-vinyl acetate barrier with an oxygen permeability of $30 \mathrm{~cm}^{3} \mathrm{~m}^{-2} 24 \mathrm{~h}^{-1}$ at $23{ }^{\circ} \mathrm{C}$ and a rate of permeability to water steam of $10 \mathrm{~g} \mathrm{~m}^{-2} 24 \mathrm{~h}^{-1}$, and kept refrigerated in the chamber at $18{ }^{\circ} \mathrm{C}$.

Three salami formulations were evaluated: the $1^{\text {st }}$, containing only a commercial starter culture (control); the $2^{\text {nd }}$ containing the commercial starter plus $L$. acidophilus; and the $3^{\text {rd }}$, containing the commercial starter culture plus $B$. lactis.

The health aspects of these two probiotic strains are related to adherence and colonization, which are two important attributes because these traits most likely prolong the amount of time that a probiotic strain can reside and survive in the intestinal tract (Lee et al., 2004). When binding to the intestinal mucosa, both probiotic strains may also exclude or reduce the population of pathogenic bacteria adhering to or colonizing the intestine. Another important characteristic is the production of acids, hydrogen peroxide and bacteriocin (lactacin B) by $L$. acidophilus NCFM) as part of its antipathogenic activities.

A reduction in lactose maldigestion or symptoms in lactase-deficient individuals, as well as improved bile sensitivity and acid tolerance, are the main attributes of lactase availability in vivo (Mustapha et al., 1997). A comparison of certain strains of bifidobacteria with Lactobacillus NCFM also showed that the lactase activity was equivalent (Hughes and Hoover, 1995).

\section{Experimental design}

To collect physicochemical data, a completely randomized design was used, considering batches of 3 $\mathrm{kg}$ of salami sausage each as an experimental unit. Each treatment was processed three times: control (without probiotics), La (with $10 \mathrm{~g} \mathrm{~kg}^{-1}$ L. acidophilus added) and $\mathrm{Bl}$ (with $10 \mathrm{~g} \mathrm{~kg}^{-1} B$. lactis added). Samples of the raw sausages (sausage batter) and ripening/dry sausages were subjected to a physicochemical analysis of $\mathrm{pH}$, color, water activity, weight loss and acidity and a microbiological analysis. To generate sensory data, a randomized complete-block experimental design was used to present samples to consumers, considering the subjects as blocks.

\section{Physicochemical and Microbiological Analyses}

To evaluate the effect of the probiotic cultures on the color of the raw sausage and the dry sausage, measurements were performed using a Minolta instrument. Before the execution of the process, the colorimeter was standardized against a white tile $(\mathrm{Y}=$ 93.7, $\mathrm{x}=0.3160$ and $\mathrm{y}=0.3323$ ) using a standard D65 and $10^{\circ}$ illuminant observer. Data were collected in the CIELAB color space. The $\mathrm{L}^{*}, \mathrm{a}^{*}$ and $\mathrm{b}^{*}$ color coordinates were measured based on three pieces from each treatment and were collected from the cross-section of products, using the mean values for statistical analysis.

The $\mathrm{pH}$ was determined using an electrode with a penetration probe coupled to a calibrated portable $\mathrm{pH}$ meter. The samples were analyzed in triplicate per treatment, and the mean value was obtained from the raw-batter sausages after mixing and at the end of the fermentation process. In ripening and dry sausages, the $\mathrm{pH}$ was measured in three pieces from each treatment, with three readings for each piece, similar to the color measurements. The $\mathrm{pH}$ of the dry sausages was measured directly from the sausage.

The lactic acid content was determined using a Brazilian methodology (Brasil, 1999) that is based on the neutralization of free hydrogen ions up to the equivalence point using $0.1 \mathrm{M}$ sodium hydroxide solution and a phenolphthalein indicator. For the determination of acidity, $10 \mathrm{~g}$ samples of three dry sausages from each treatment were randomly selected, crushed and homogenized with $200 \mathrm{~mL}$ of distilled water in an Ultra-Turrax homogenizer for $1 \mathrm{~min}$. This solution was transferred to a $250 \mathrm{~mL}$ volumetric flask, and the volume was completed with distilled water. This solution was filtered, and $25 \mathrm{~mL}$ of the filtrate was added to $75 \mathrm{~mL}$ of distilled water and three drops of $1 \%$ phenolphthalein alcohol solution. For the blank test, $100 \mathrm{~mL}$ of distilled water was prepared. The turning point was the appearance of a light pink color persisting for $30 \mathrm{~s}$.

The water activity of salami samples was determined using a $4 \mathrm{~T}$ AquaLab water activity meter. The slices of salami, approximately $3 \mathrm{~mm}$ in thickness were placed in capsules suitable for analysis, with the exception of the raw sausage, which was spread over the bottom of the capsules using a spatula before analysis.

To determine the weight loss of pieces of salami during the 13 days of drying, three pieces from each treatment were randomly selected from three different 
locations in the dryer (front, right side and left side). The pieces were individually labeled with coded rings and weighed daily on a semi-analytical balance until the end of the process. Thus, for each treatment, based on the initial total weight of the three pieces, the daily weight loss was calculated (in grams) and expressed in terms of percentage change (Figure 1).

The total LAB count was measured in salami using the methodology described by Grosso and FávaroTrindade (2004). Samples were prepared in a laminar flow hood that had been previously exposed to UV light for $30 \mathrm{~min}$. Next, $25 \mathrm{~g}$-samples of salami from each treatment were placed in $225 \mathrm{~mL}$ of peptone water in sterile plastic bags. The samples were homogenized for $2 \mathrm{~min}$. Ten-fold dilutions, from $10^{-1}$ to $10^{-8}$, were performed in duplicate.

For L. acidophilus counts, approximately $13 \mathrm{~mL}$ of MRS Agar were prepared according to the manufacturer's instructions and were added to plates and homogenized. The plates were incubated anaerobically for $72 \mathrm{~h}$ at 43 ${ }^{\circ} \mathrm{C}$ in a BOD incubator (Tharmaraj and Shah, 2003). For $B$. lactis counts, the agar was modified according to the protocol of Grosso and Fávaro-Trindade (2004) by adding $5 \mathrm{~g} \mathrm{~kg}^{-1} \mathrm{~L}$-cysteine solution, $10 \mathrm{~g} \mathrm{~kg}^{-1}$ chloride lithium solution, $0.1 \mathrm{~g} \mathrm{~kg}^{-1}$ aniline blue and $0.5 \%$ dicloxacillin solution. The plates were incubated anaerobically for 72 $\mathrm{h}$ at $37^{\circ} \mathrm{C}$ in a BOD incubator. The total LAB count was evaluated on a composite sample of three pieces of dried salami that were randomly chosen.

\section{Sensory analysis}

Cultures different from traditional meat starter cultures may have a negative impact on the sensory properties of salami. To determine whether the addition of probiotic cultures affected the sensory characteristics of the developed salami, an acceptance test was performed with 96 consumers.

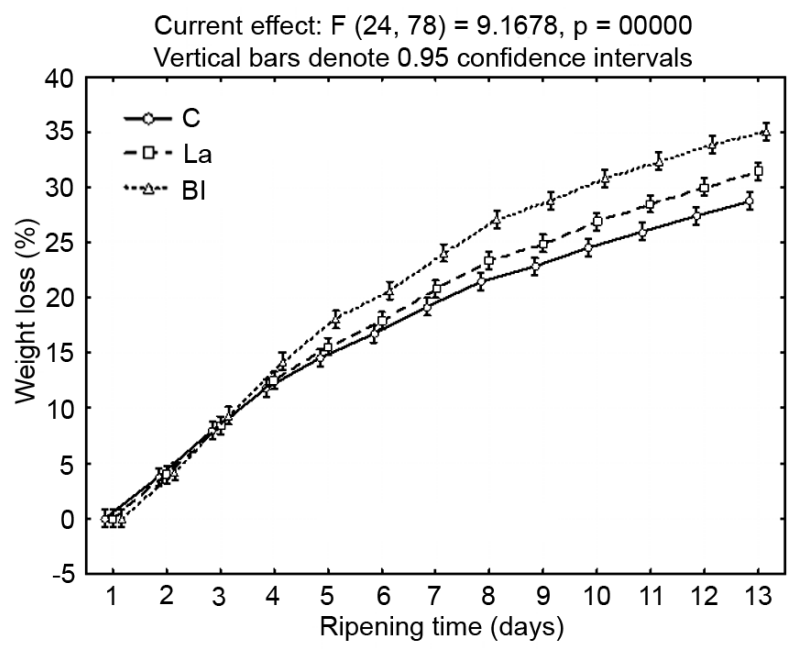

Figure 1 - Weight loss of the probiotic and control salamis and control during 13 days of ripening. $\mathrm{C}=$ control, $\mathrm{La}=$ Lactobacillus acidophilus, $\mathrm{Bl}=$ Bifidobacterium lactis.
Habitual salami consumers were recruited from the University of São Paulo in Piracicaba, in the state of São Paulo, Brazil. Of the 96 consumers recruited, 75 $\%$ were female, and $25 \%$ were male, with ages ranging from 20 to 50 years old. The selection criteria required that a subject consume salami at least once per week and present a degree of liking of salami equal to or higher than "like moderately" on a nine-point hedonic scale.

For the sensory tests, the consumers were accommodated in individual tasting booths, where they received instructions on the use of the scale, the nature of the products and the type of evaluation to be performed. A slice of each salami sample was served under white light and on disposable white plastic plates coded with random three-digit numbers. The three salami samples, presented in random order according to a randomized complete-block design, were evaluated by each consumer in a monadic way.

After an appearance evaluation, the consumers were asked to taste the product and to evaluate how much they liked or disliked each sample with respect to texture, flavor and overall acceptance using a ninepoint hedonic scale $(1=$ disliked extremely, $9=$ liked extremely) (Meilgaard et al., 2007). During the sensory evaluation, an interval of 5 minutes was given between samples to avoid fatigue. Lastly, the consumers evaluated their purchase intention for the tested products using a five-point structured scale $(1=$ certainly will not buy, 5 $=$ certainly will buy).

\section{Statistical analysis}

The physiochemical measures of the experimental treatments were analyzed using a one-way ANOVA $(p \leq$ 0.05). The acceptance responses were analyzed by Pearson correlation analysis $(p \leq 0.05)$ and a two-way ANOVA $(p$ $\leq 0.05$ ), including the effects of consumers and samples in the statistical model. To evaluate the differences in physicochemical characteristics and acceptance among the samples, paired comparisons of the means were performed using the Tukey HSD test $(p \leq 0.05)$.

\section{Results and Discussion}

\section{Color}

At the beginning of the processing of salamis as meat batter and in the ripening/dry sausages, no differences $(p \leq 0.05)$ in color were found between salamis fermented by probiotic cultures and the control (Table 1). A reduction from 56.33 to 40.85 was observed in the overall mean $L^{*}$ of the raw sausage from the beginning of processing until salami ripening (Table 1). This decline was related to the processes of curing, drying and ripening the sausage. The drying process specifically aids the decrease in $\mathrm{L}^{*}$ because there are concentrations of solids in the product due to dehydration (Pérez-Alvarez et al., 1999). The $L^{*}$ values obtained in this experiment were higher than the brightness of 36 found by Garcia et al. (2000) in Italian salami after 20 days of processing. 
For the redness parameter $\left(\mathrm{a}^{*}\right)$, the overall mean in salamis increased from 13.59 in the raw sausage to 14.86 in the dry sausage (Table 1). This increase was related to the process of ripening/drying salami. The reaction of myoglobin, which is the major pigment in meat, with nitric oxide from the heating process forms nitrosomyoglobin, which is a characteristic pigment in cured meats (Zanardi et al., 2002). An increase in a* with processing was also observed in Italian salami by Campagnol et al. (2007) and Garcia et al. (2000). The values obtained in the current study are consistent with those found in Italian salami sold in Brazil, although slightly higher values (17.5 to 17.8) were observed by Garcia et al. (2000).

In contrast to redness $\left(\mathrm{a}^{*}\right)$, the intensity of yellow $\left(b^{*}\right)$ greatly decreased during storage, dropping from 13.89 in raw sausage to 6.46 in dry sausage (Table 1). This decrease was likely due to oxygen consumption by microorganisms in the starter culture during their exponential growth phase, producing a decrease in oxymyoglobin. Additionally, the reaction of nitric oxide with myoglobin to form nitrosomyoglobin may have also contributed to the decrease in the concentrations of myoglobin and oxymyoglobin, leading to the reduction in the $b^{*}$ value (Pérez-Alvarez et al., 1999).

The probiotic cultures did not interfere with the color parameters of salami. In sausages, these results are desirable because the color is an aspect of great commercial value that is associated with product quality and is a determinant of acceptance by consumers.

\section{pH, Water Activity and Lactic acid content}

The ANOVA analysis of the $\mathrm{pH}$ of the raw sausage batter showed no differences $(p \leq 0.05)$ among the means of the three treatments, which ranged from 5.88 to 5.97 (Table 2). After fermentation, the control had an average $\mathrm{pH}$ of 5.28 , whereas the $\mathrm{La}$ and $\mathrm{Bl}$ treatments had lower average ( $p \leq 0.05)$ values (4.67 and 4.58, respectively). These lower $\mathrm{pH}$ values in the probiotic samples could have been due to the production of lactic acid and other organic acids by Lactobacillus acidophilus and Bifidobacterium lactis. This difference in $\mathrm{pH}$ was maintained during the ripening/dry sausage stage, with a lower value for $\mathrm{Bl}$, followed by $\mathrm{La}$, and a higher value for the control ( $p \leq 0.05$ ) (Table 2). These results showed that the probiotic resulted in a lower $\mathrm{pH}$ end-product. These findings are similar to those of Kaya and Aksu (2005), who also reported the highest $\mathrm{pH}$ value in the control group in relation to the probiotic groups $\mathrm{SC}+\mathrm{La} 5$ (starter culture and $L$. acidophilus) and $\mathrm{SC}+\mathrm{Bb} 12$ (starter culture and $B$. lactis) in sliced dry fermented sausage known as "sucuk".

In dry sausages, the probiotic groups $\mathrm{La}$ and $\mathrm{Bl}$ had increased $\mathrm{pH}$ values (Table 2). These high $\mathrm{pH}$ values were likely due to increased proteolytic activity, with the formation of peptides, amino acids and nonprotein nitrogen compounds (Durá et al., 2004), and are consistent with findings in other studies of fermented and dry sausages (Greco et al., 2005) and Italian salami (Garcia et al., 2000).

The $\mathrm{pH}$ of the salami fermented with $B$. lactis was lower $(p \leq 0.05)$ than the $\mathrm{pH}$ of the control and the salami fermented with $L$. acidophilus, indicating a faster and more effective production of lactic acid, with consequent decreases in $\mathrm{pH}$ (Table 2). The tolerance of $\mathrm{Bl}$ to acidic conditions was specific to our processing conditions because Tamine et al. (2005) reported that $\mathrm{La}$ is generally more tolerant to acidic conditions than are bifidobacteria, whose growth decreases below $\mathrm{pH}$ 5.5. The reduction in $\mathrm{pH}$ made it possible to reach the isoelectric point of meat protein, and the approximation of the molecules facilitated the loss of water in the $\mathrm{Bl}$ treatment (Figure 1). This process was also reflected in the acceptance of the texture (Table 3); the Bl salami had an average acceptance that was lower $(p \leq 0.05)$ than that of the control and the La salami.

The mean water activity values measured in the raw sausages from the probiotic treatments differed $(p \leq 0.05)$ from the water activity in the control treatment, with averages of 0.98 and 0.99 for the La and

Table $1-$ Mean ${ }^{\S}\left( \pm\right.$ standard deviation) $L^{*}, a^{*}$ and $b^{*}$ of raw sausages and dry sausages.

\begin{tabular}{|c|c|c|c|c|c|c|}
\hline \multirow{2}{*}{ Treatment } & \multicolumn{3}{|c|}{ Sausage batter } & \multicolumn{3}{|c|}{ Dry sausage } \\
\hline & $L^{*}$ & $a^{*}$ & $b^{*}$ & $L^{*}$ & $a^{*}$ & $b^{*}$ \\
\hline Control & $56.12 \pm 2.330^{a}$ & $13.82 \pm 1.279^{a}$ & $14.52 \pm 1.241^{\mathrm{a}}$ & $40.98 \pm 2.944^{a}$ & $14.86 \pm 0.903^{a}$ & $6.76 \pm 1.017^{a}$ \\
\hline L. acidophilus & $55.54 \pm 1.081^{a}$ & $11.98 \pm 0.801^{\mathrm{a}}$ & $13.44 \pm 0.446^{a}$ & $41.08 \pm 0.493^{a}$ & $14.98 \pm 0.913^{\mathrm{a}}$ & $6.63 \pm 0.534^{a}$ \\
\hline B. lactis & $57.34 \pm 2.062^{a}$ & $11.97 \pm 1.360^{\mathrm{a}}$ & $13.71 \pm 0.828^{a}$ & $40.49 \pm 0.699^{a}$ & $13.59 \pm 1.041^{\mathrm{a}}$ & $5.99 \pm 0.386^{a}$ \\
\hline
\end{tabular}

sMeans followed by different letters in the column differ $(p \leq 0.05)$.

Table 2 - Mean ${ }^{\S}$ ( \pm standard deviation) $\mathrm{pH}$, Aw and acidity of sausage batter and dry sausages.

\begin{tabular}{|c|c|c|c|c|c|c|c|}
\hline \multirow[t]{2}{*}{ Treatment } & \multicolumn{3}{|c|}{$\mathrm{pH}$} & \multicolumn{2}{|c|}{ Aw } & \multicolumn{2}{|c|}{$\begin{array}{c}\text { Acid lactic content } \\
\text { (g of lactic acid/100 g) }\end{array}$} \\
\hline & Sausage batter & After fermentation & Dry sausage & Sausage batter & Dry sausage & Sausage batter & Dry sausage \\
\hline Control & $5.97 \pm 0.035^{a}$ & $5.28 \pm 0.015^{a}$ & $5.23 \pm 0.021^{a}$ & $0.97 \pm 0.006^{b}$ & $0.89 \pm 0.001^{a}$ & $0.09 \pm 0.002^{c}$ & $0.19 \pm 0.001^{c}$ \\
\hline L. acidophilus & $5.96 \pm 0.038^{a}$ & $4.67 \pm 0.040^{b}$ & $4.80 \pm 0.036^{b}$ & $0.98 \pm 0.003^{a}$ & $0.87 \pm 0.006^{b}$ & $0.12 \pm 0.001^{\mathrm{b}}$ & $0.26 \pm 0.002^{b}$ \\
\hline B. lactis & $5.88 \pm 0.059^{a}$ & $4.58 \pm 0.021^{c}$ & $4.71 \pm 0.012^{c}$ & $0.99 \pm 0.002^{a}$ & $0.84 \pm 0.005^{c}$ & $0.14 \pm 0.001^{\mathrm{a}}$ & $0.29 \pm 0.001^{a}$ \\
\hline
\end{tabular}

\$Means followed by different letters in the column differ $(p \leq 0.05)$. 
Table 3 - Mean ${ }^{\S}$ ( \pm standard deviation) acceptance of appearance, texture and flavor and overall acceptance scores of salamis ( $n=$ 96 consumers).

\begin{tabular}{lccc}
\hline \multirow{2}{*}{ Attribute } & \multicolumn{3}{c}{ Treatment } \\
\cline { 2 - 4 } Appearance & Control & L. acidophilus & B. lactis \\
Texture & $7.1 \pm 1.59^{\mathrm{a}}$ & $7.3 \pm 1.34^{\mathrm{a}}$ & $7.2 \pm 1.28^{\mathrm{a}}$ \\
Flavor & $7.3 \pm 1.47^{\mathrm{a}}$ & $6.8 \pm 1.71^{\mathrm{a}}$ & $6.4 \pm 1.67^{\mathrm{b}}$ \\
Overall acceptance & $6.9 \pm 1.81^{\mathrm{a}}$ & $7.2 \pm 1.65^{\mathrm{a}}$ & $6.8 \pm 1.65^{\mathrm{a}}$ \\
SMeans followed by different letters in the row differ $(p<0.05)$.
\end{tabular}

$\mathrm{Bl}$ treatments, respectively, and an average of 0.97 for the control treatment (Table 2). Additionally, in the dry sausages, differences between treatments $(p \leq 0.05)$ were observed (Table 2). The control had an average water activity of 0.89 , and the $\mathrm{La}$ and $\mathrm{Bl}$ treatments had average values of 0.87 and 0.84 , respectively. The lower water activities of the $\mathrm{La}$ and $\mathrm{Bl}$ treatments were related to the decrease in $\mathrm{pH}$. When the $\mathrm{pH}$ approaches the isoelectric point of proteins, as observed in the probiotic treatment groups, a decrease in water retention capacity occurs, thus facilitating dehydration and, consequently, the reduction in water activity in sausages (Mauriello et al., 2004).

The water activity values obtained for the two probiotic treatments ranged from 0.84 to 0.87 , and the control presented activity of 0.89 . The values approached the range of 0.87 to 0.88 observed by Garcia et al. (2000) and are consistent with the findings of Herrero et al. (2007), who reported values between 0.83 and 0.89 . The values were also below 0.90 , which is the maximum value recommended in the Brazilian standards for Italian-type salami (Brasil, 2000).

The probiotics $\mathrm{La}$ and $\mathrm{Bl}$ are of importance in fermented sausages such as salami because of these organisms' ability to provide rapid and effective fermentation and acidification, which were enhanced $(p$ $\leq 0.05$ ) as compared with these processes in the control treatment (Table 2), thus protecting the fermented sausages from spoilage and pathogenic bacteria (Pennacchia et al., 2004). This phenomenon was due to the fact that in addition to the probiotic cultures, the experimental treatments contained a starter culture, i.e., $1 \%$ more bacteria compared with the control treatment, producing higher fermentation of the sugars (sucrose and dextrose). These results show consistency among the parameters of $\mathrm{pH}, \mathrm{Aw}$ and lactic acid content that were examined in this study. Thus, the higher lactic acid content in the probiotic groups seems to be directly related to the decrease in $\mathrm{pH}$ during the fermentation of salami (4.7 to 4.8 ), which is important to ensuring the safety and texture of salami products.

\section{Weight Loss}

Figure 1 clearly shows the exponential behavior of the weight loss curves, in which the addition of $B$. lactis was associated with the highest rate of weight loss (35\%) during the drying period, followed by treatment with $L$. acidophilus (31\%) and the control treatment (29 $\%$ ), which presented the lowest rate. From the $4^{\text {th }}$ day of drying onwards, $\mathrm{Bl}$ salamis began to suffer a greater loss of weight than did control and La salami sausages, and that over the drying time, the $\mathrm{Bl}$ salamis exhibited more rapid weight loss. La salami experienced weight loss at an intermediate velocity during the drying period.

The greater weight loss observed in the probiotic treatment groups was related to the increased acidification of the raw sausages, which facilitated the weight loss of the samples. In turn, this condition was related to the lower $\mathrm{pH}$ found in these treatments, which resulted in greater water loss during processing, given that the $\mathrm{pH}$ is one of the main factors that influences the diffusion of water from the inside to the surface of salami. The weight loss results were within the range reported by certain authors, such as $27 \%$ in Milano salami (Zanardi et al., 2002), between 30 and $32 \%$ in fermented sausages (Gøtterup et al., 2008) and $40 \%$ in sausages fermented by L. rhamnosus cultures after 28 days of processing (Erkkilä et al., 2001). Other authors reported higher values, achieving weight losses of between 40 and $45 \%$ in Italian salami (Garcia et al., 2000; Cirolini, 2010) and of $59 \%$ in salami fermented by $L$. plantarum cultures after 20 days of processing (Campagnol et al., 2007). These data demonstrate the large variations in the processing of fermented sausage and dry sausage, which may be due to formulation, raw materials and processing, among other factors.

After the drying period, the salamis were stored in vacuum packages, preventing gas exchange or a loss of moisture. Hence, weight loss was not determined during storage. Thus, the incorporation of probiotic cultures presented an effect $(p \leq 0.05)$ on the weight loss of Italian salami, which was more evident in the $\mathrm{Bl}$ treatment. However, the weight loss values reached at the end of the drying period by both the $\mathrm{Bl}(35.1 \%)$ and the La $(31.5 \%)$ salamis were within the parameters (30 to 40 $\%)$ that are considered ideal (Rust, 1994) because weight losses greater than these values hamper the commercial viability of fermented sausages.

\section{Microbiological analysis}

The probiotic cultures had an ability to multiply, and therefore viability, in a fermented meat product, with an increase in the number of viable cells in the first few days of fermentation. At the beginning of the process (raw sausage), the initial counts of viable cells of $L$. acidophilus and $B$. lactis were $9 \times 10^{8}$ and $1 \times 10^{8} \mathrm{cfu} \mathrm{g}^{-1}$, respectively. In the control sample, the count of LAB was $1 \times 10^{8} \mathrm{cfu} \mathrm{g}^{-1}$. In the ripening and dry sausages, the $\mathrm{La}$ and $\mathrm{Bl}$ treatments yielded values of $2 \times 10^{8} \mathrm{cfu} \mathrm{g}^{-1}$ and $1.7 \times 10^{9} \mathrm{cfu} \mathrm{g}^{-1}$, respectively, compared with $1 \times 10^{8} \mathrm{cfu} \mathrm{g}^{-1}$ in the control sample. These results indicate that there was an increase in the presence of these probiotic strains in the salami because the viable cell count was from $10^{8}$ to $10^{9} \mathrm{cfu} / \mathrm{g} /$ day, which is the amount stipulated by Brazilian law, based on the daily portion of food (ANVISA, 2007). La and Bl 
grew more quickly than did commercial starter cultures (Staphylococcus xylosus and Pediococcus pentosaceus) that are normally used for meat fermentation. The probiotic strains exhibited an acceptable acidification rate and tolerated certain detrimental factors within fermented sausage, such as $\mathrm{NaCl}$ at $2.5 \% \mathrm{w} / \mathrm{w}$, $\mathrm{pH}$ values of 4.7 to 4.8, Aw values of 0.84 to 0.87 and the drying process, and that the strains should be able to grow to numbers that have health-promoting effects (Holko et al., 2013).

\section{Consumer test}

The ANOVA of the acceptance data showed no differences $(p \leq 0.05)$ in the mean acceptance of appearance, flavor and in the overall acceptance of the salami. However, differences $(p \leq 0.05)$ in the acceptance of texture were found. Table 3 shows a good acceptance of the two types of salami sausages by consumers. The salami fermented with the probiotic $L$. acidophilus had an acceptance similar to that of the control salami, with scores for the evaluation of appearance, flavor and overall quality averaging approximately 7.0 ("like moderately"). In texture, the salami fermented with $B$. lactis presented an average score of 6.4 ("like slightly"), which was lower than that of the control and the La salami ( $p \leq 0.05)$, which had an average acceptance of approximately 7.0 ("like moderately") on a nine-point hedonic scale. This result can be attributed to the fact that $\mathrm{Bl}$ produces acids other than lactic acid, such as acetic and butyric acids (Meile et al., 1997), which can affect the sensory quality of the product and thus acceptance.

Another explanation is that the water activity of the salami fermented with $B$. lactis was lower $(p \leq 0.05)$ than the water activity of the salami fermented with $L$. acidophilus, thereby facilitating dehydration and making the sample more dry and tough. Nonetheless, the salami fermented with probiotic cultures attained a high level of acceptance among consumers, and especially the salami treated with $L$. acidophilus, which showed an average acceptance of approximately 7.0 (like moderately) for all attributes, similar to the control salami. The lower rate of purchase intention for the $B$. lactis salami may have been due to the lower acceptance $(p \leq 0.05)$ of its texture as compared with the texture of $L$. acidophilus salami.

The results obtained in our work and other studies showed the same results as those reported by Muthukumarasamy and Holley (2006), who evaluated the acceptance of salami treated with or without Lactobacillus reuteri (encapsulated and free). Thus, the addition of probiotic cultures could be a good option for meat products.

\section{Correlation analysis}

Positive correlations $(p \leq 0.05)$ were observed between overall acceptance and appearance, texture and flavor. Flavor was the attribute that most influenced the overall acceptance of the sausages $(\mathrm{r}=0.84)$, followed by texture $(\mathrm{r}=0.71)$ and, with lower influence, appearance $(r=0.50)$. These important findings show that the drivers of consumer acceptance were mainly the flavor and the texture, which most likely determine the decision to purchase the product.

\section{Purchase intention}

The results of the purchase intention analysis show a high purchase intention for the three salamis (Table 4). Thus, $65 \%$ of the interviewed consumers affirmed that they will most likely or certainly will purchase the $L$. acidophilus salami, positively contributing to their buying intention, whereas this percentage was $53 \%$ for the $B$. lactis salami and $58 \%$ for the control salami. The lower rate of purchase intention for the $B$. lactis salami may have been due to the lower acceptance $(p \leq 0.05)$ of its texture as compared with the texture of $L$. acidophilus salami. Muthukumarasamy and Holley (2006) showed that $78 \%$ of the consumers interviewed reported that the addition of probiotics to salami sausages positively contributed to their buying intention. The probiotic salamis developed in the current study have great potential for commercialization, especially the salami treated with $L$. acidophilus, which presented better texture acceptance and higher purchase intention among consumers.

\section{Conclusions}

The use of probiotic cultures had positive effects on the physicochemical, microbiological and sensory properties evaluated. The $\mathrm{pH}$, acidity, Aw, weight loss and microbiological counts were within the ranges that are considered to be ideal for the formulation of fermented sausages. Moreover, the addition of probiotic cultures was advantageous because the Italian salamis had high acceptance among consumers and similar performance to the control. These products have great sales potential in the consumer market. This implication is reinforced by the increasing global trend of consuming healthy foods.

\section{Acknowledgments}

This study was financially supported by the São Paulo Research Foundation (FAPESP) Project 2007/005752, and by Danisco, Chr. Hansen, Viscofan, IBRAC and Cryovac, which supplied probiotics, starter cultures, additives and packaging.

\section{References}

Agência Nacional de Vigilância Sanitária [ANVISA]. 2007. Foods with allegations of functional properties and or health, novel foods / ingredients, bioactive substances and probiotics, list of approved claims functional property $=$ Alimentos com alegações de propriedades funcionais e ou de saúde, novos alimentos/ingredientes, substâncias bioativas e probióticos; lista de alegações de propriedade funcional aprovadas. Available at: http://www.anvisa.gov.br/alimentos/http://www.anvisa.gov.br/ alimentos/comissoes/tecno_lista_alega.htm > Accessed Feb 19, 2010 (in Portuguese). 
Brasil. Ministério da Agricultura, Pecuária e Abastecimento. 1999. Normative Instruction 20 dated 21 July 1999. Formalizes the physicochemical analytical methods for control of meat products and their ingredients - salt and brine, according to the Annex of this normative instruction, determining which are used in the system of animal laboratory of the department of animal defense = Instrução Normativa $\mathrm{n}^{\circ} 20$, de 21 de julho de 1999. Oficializa os métodos analíticos físico-químicos, para controle de produtos cárneos e seus ingredientes - sal e salmoura, em conformidade ao anexo desta instrução normativa, determinando que sejam utilizados no sistema de laboratório animal do departamento de defesa animal. Diário Oficial, da União, Seção 1, p.10, 27 julho 1999. Brasília, DF, Brazil (in Portuguese).

Brasil. Ministério da Agricultura, Pecuária e Abastecimento. 2000. Normative Instruction 22, dated 31 July, 2000. Approves the identifying of technical regulations and quality of coppa , jerked beef, Parma type ham, raw ham, salami, "salaminho", German type salami, Calabrian type salami, friolano type salami, Neapolitan type salami, hamburger type salami, Italian salami, Milano type salami, colonial sausage and pepperoni $=$ Instrução Normativa $n^{\circ} 22$, de 31 de julho de 2000. Aprovar os regulamentos técnicos de identidade e qualidade de copa, de jerked beef, de presunto tipo Parma, de presunto cru, de salame, de salaminho, de salame tipo alemão, de salame tipo calabrêsa, de salame tipo friolano, de salame tipo napolitano, de salame tipo hamburguês, de salame tipo italiano, de salame tipo milano, de lingüiça colonial e pepperoni. Diário Oficial, da União, Seção 1, p.1503, agosto 2000. Brasília, DF, Brazil (in Portuguese).

Campagnol, P.C.B.; Fries, L.L.M.; Terra, N.N.; Santos, B.A.; Furtado, A.S. 2007. Salami sausage prepared with Lactobacillus plantarum fermented in porcine plasma culture medium. Ciência e Tecnologia de Alimentos 27: 883-889 (in Portuguese, with abstract in English).

Cirolini, A.; Fries, L.L.M.; Terra, N.N.; Milani, L.I.G.; Urnau, D.; dos Santos, B.A.; Cervo, G.D. 2010. Fermented italian sausage elaborated with native starter cultures. Ciência e Tecnologia Alimentaria 30: 171-179 (in Portuguese, with abstract in English).

Dali, C.; Davis, R. 1998. The biotechnology of lactic acid bactéria with emphasis on application in food safety and human health. Agricultural and Food Science in Finland 7: 219-250.

Durá, M.A.; Flores, M.; Toldrá, F. 2004. Effect of Debaryomyces spp. on the proteolysis of dry-fermented sausages. Meat Science 68: 319-328.

Erkkilä, S.; Suihko, M.L.; Eerola, S.; Petäjä, E.; Mattila-Sandholm, T. 2001. Dry sausage fermented by Lactobacillus rhamnosus strains. International Journal of Food Microbiology 64: 205210.

Food and Agriculture Organization [FAO]. 2001. Health and Nutritional Properties of Probiotics in Food Including Powder Milk with Live Lactic Acid Bacteria. FAO/WHO, Rome, Italy.

Garcia, F.T.; Gagleazzi, U.A.; Sobral, P.J.A. 2000. Variation of physical and chemical properties of Italian salami during fermentation and drying. Brazilian Journal of Food Technology 3: 151-158 (in Portuguese, with abstract in English).
Gopal, P.K.; Prasad, J.; Smart, J.; Gill, H.S. 2001. In vitro adherence properties of Lactobacillus rhamnosus DR20 and Bifidobacterium lactis DR10 strains and their antagonistic activity against an enterotoxigenic Escherichia coli. International Journal of Food Microbiology 67: 207-216.

Gøtterup, J.; Olsen, K.; Knøchel, S.; Tjener, K.; Stahnke, L.H.; Møller, J.K.S. 2008. Colour formation in fermented sausages by meat-associated staphylococci with different nitrite- and nitrate-reductase activities. Meat Science 78: 492-501.

Greco, M.; Mazzette, R.; De Santis, E.P.L.; Corona, A.; Cosseddu, A.M. 2005. Evolution and identification of lactic acid bacteria isolated during the ripening of Sardinian sausages. Meat Science 69: 733-739.

Grosso, C.R.F.; Fávaro-Trindade, C.S. 2004. Stability of free and immobilized Lactobacillus acidophilus and Bifidobacterium lactis in acidified milk and of immobilized B. lactis in yoghurt. Brazilian Journal of Microbiology 35: 151-156.

Herrero, A.M.; Ordóñez, J.A.; De Avila, R.; Herrans, B.; De la Hoz, L.; Cambero, M.I. 2007. Breaking strength of dry fermented sausages and their correlation with texture profile analysis (TPA) and physic-chemical characteristics. Meat Science 77: 331-338.

Holko, I.; Hrabě, J.; Ŝalaková, A.; Rada, V. 2013. The substitution of a traditional starter culture in mutton fermented sausages by Lactobacillus acidophilus and Bifidobacterium animalis. Meat Science 94: 275-279.

Hughes, D.B.; Hoover, D.G. 1995. Viability and enzymatic activity of bifidobacteria in milk. Journal of Dairy Science 78: 268-276.

Kaya, M.; Aksu, M.I. 2005. Effect of modified atmosphere and vacuum packaging on some quality characteristics of sliced 'sucuk' produced using probiotics culture. Journal of the Science of Food and Agriculture 85: 2281-2288.

Lee, Y.K.; Ho, P.S.; Low, C.S.; Arvilommi, H.; Salminen, S. 2004. Permanent colonization by Lactobacillus casei is hindered by low rate of cell division in mouse gut. Applied Environmental Microbiology 70: 670-674.

Martín, A.; Colín, B.; Aranda, E.; Benitom, M.J.; Córdoba, M.G. 2007. Characterization of Micrococcaceae isolated from Iberian dry-cured sausages. Meat Science 75: 696-708.

Mauriello, G.; Casaburi, A.; Blaiotta, G.; Villani, F. (2004). Isolation and technological properties of coagulase negative staphylococci from fermented sausages of Southern Italy. Meat Science 67: 149-158.

Meile, L.; Ludwing, W.; Rueger, U.; Gut, C.; Kaufmann, P.; Dasen, G.; Wenger, S.; Teuber, M. 1997. Bifidobacterium lactis sp.nov.: a moderately oxygen tolerant species isolated from fermented milk. Systematic and Applied Microbiology 20: 57-64.

Meilgaard, M.; Civille, G.V.; Thomas, C. 2007. Sensory Evaluation Techniques. CRC Press, Boca Raton, FL, USA.

Mustapha, A.; Jiang, T.; Savaiano, D.A. 1997. Improvement of lactose digestion by humans following ingestion of unfermented acidophilus milk: influence of bile sensitivity, lactose transport, and acid tolerance of Lactobacillus acidophilus. Journal of Dairy Science 80: 1537-1545.

Muthukumarasamy, P.; Holley, R.A. 2006. Microbiological and sensory quality of dry fermented sausages containing alginatemicroencapsulated Lactobacillus reuteri. International Journal of Food Microbiology 111: 164-169. 
Paramithios, S.; Drosinos, E.H.; Sofos, J.N.; Nychas, G.J. 2010. Fermentation: microbiology and biochemistry. p. 185-198. In: Toldrá, F., ed. Handbook of meat processing. Wiley-Blackwell, Hoboken, NJ, USA.

Pennacchia, C.; Ercolini, D.; Blaiotta, C.; Pepe, O.; Mauriello, C.; Villani, F. 2004. Selection of Lactobacillus strains from fermented sausages for their potential use as probiotics. Meat Science 67: 309-317

Pérez-Alvarez, J.A.; Sayas-Barberá, M.E.; Fernández-Lopez, J.; Aranda-Catalá, V. 1999. Physicochemical characteristics of Spanish-type dry-cured sausage. Food Research International 32: 599-607.

Prasad, J.; Gill, H.; Smart, J.; Gopal, P.K. 1998. Selection and characterization of Lactobacillus and Bifidobacterium strains for use as probiotics. International Dairy Journal 8: 993-1002.

Rust, 1994. Sausages products. p. 415-439. In: Price, J.; Schweigert, B., eds. The science of meat and meat products. Food \& Nutrition Press, Wetsport, CT, USA.

Sanders, M.E.; Klaenhammer, T.R. 2001. The scientific basis of Lactobacillus acidophilus NCFM functionality as a probiotic. Journal of Dairy Science 84: 319-331.
Tamine, A.Y.; Saarela, M.; Sondergaard, A.K.; Mistry, V.V.; Shah, N.P. 2005. Production and maintenance of viability probiotics micro-organisms in dairy products. p. 39-72. In: Tamine, A.Y., ed. Probiotic dairy products. Blackwell, Oxford, UK.

Tamine, Y.; Marshall, V.M.; Robinson, R.K. 1995. Microbiological and technological aspects of milks fermented by Bifidobacteria. Journal of Dairy Science 62: 151-187.

Tharmaraj, N.; Shah, N.P. 2003. Selective enumeration of Lactobacillus delbrueckii ssp. Bulgaricus, Streptococcus thermophilus, Lactobacillus acidophilus, Bifidobacteria, lactobacillus casei, Lactobacillus rhamnosus, and Propionibacterium. Journal of Dairy Science 86: 2288-2296.

Vignolo, G.; Fontana, C.; Fadda, S. 2010. Semidry and dry fermented sausages. p. 379-398. In: Toldrá, F., ed. Handbook of meat processing. Wiley-Blackwell, Hoboken, NJ, USA.

Zanardi, E.; Dorigoni, V.; Badiani, A.; Chizzolini, R. 2002. Lipid and colour stability of Milano-type sausages: effect of packing conditions. Meat Science 61: 7-14. 